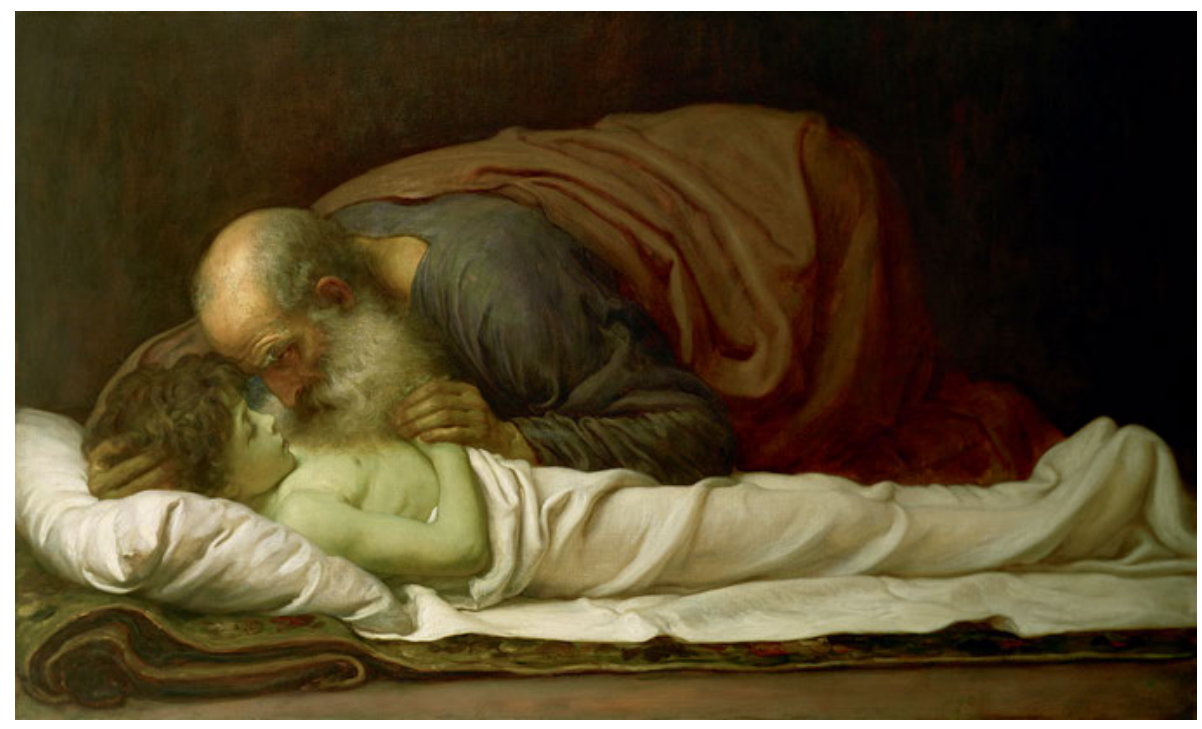

Fig. 8: Frederick Leighton, Elisha Raising the Son of the Shunammite, 1881, oil on canvas, $127 \mathrm{x}$ $174 \mathrm{~cm}$., Leighton House Museum, Royal Borrow of Kensington and Chelsea, London. Image Source: Bridgeman Images. 


\title{
A Magic Touch: Performative Haptic Acts in Biblical and Medieval Jewish Magic
}

\author{
"The sense of touch [...] is a disgrace to us." \\ Maimonides, Guide of the Perplexed, 2.36
}

Shaking hands, the laying on of hands, embracing with the arms, and kissing with the lips are some modes of touching which do not only establish physical contact between different persons, but can also have symbolic significance in the fields of human communication and ritual, or, more generally, in culture and religion. ${ }^{1}$ Thus, it is not surprising that bodily contact and touching persons, objects, and places is also an extremely important issue in Judaism. At first in a negative way, detailed instructions found in biblical and also halakhic literature concern restrictions or even prohibitions on direct bodily contact with persons, objects, and places. These instructions aim to define and cover crucial concepts such as sanctity/profanity and purity/impurity. Yet there are many customs or practices involving touch that are undeniably evident in the Jewish religion; for example, the Jewish worshiper kisses the Torah scroll before reciting it in the synagogue or kisses or touches the mezuzah on the doorposts before entering or leaving a room or house. In fact, from a phenomenological perspective these practices can be interpreted as magical. In the following, I would like to focus on a couple of Hebrew texts related to magical acts and rituals with an emphasis on the meaning of touching.

In general, when we define Judaism as an orthopractical religion, this means that doing the right thing is more critical than merely placing one's belief in certain dogmas. Concerning Jewish magic, J.L. Austin's definition of performative speech acts"how to do things with words"-is an excellent description of the essential characteristic. ${ }^{2}$ According to Austin, a performative utterance refers to a performative doing; that is, it can make something happen just by the right words and formulas being spoken by the right person in the right setting. If we adapt this concept to the field of magic, for instance, saying the self-referential phrase "I adjure you..." is a performative speech act implying an adjuration of supernatural powers in order to

1 See, e.g., Geoffrey Parrinder, “Touching," in Encyclopedia of Religion, Second Edition, ed. Lindsay Jones (Detroit: Thomson Gale, 2005), 13:9255-60; Frederick Mathewson Denny, "Hands," in Encyclopedia of Religion, Second Edition, 6:3769-71.

2 See J.L. Austin, How to Do Things with Words: The William James Lectures Delivered at Harvard University, ed. J.O. Urmson (Oxford: Clarendon Press, 1962); see also the important contribution by John R. Searle, Speech Acts: An Essay in the Philosophy of Language (Cambridge: Cambridge University Press, 1969). For the vast scholarly discussion of rituals and performance, see, e.g., the well-selected anthologies in Andréa Belliger and David J. Krieger, eds., Ritualtheorien: Ein einführendes Handbuch (Opladen: Westdeutscher Verlag, 1998) and Uwe Wirth, ed., Performanz: Zwischen Sprachphilosophie und Kulturwissenschaften (Frankfurt am Main: Suhrkamp, 2002). 
coerce them to be subservient. Thus, according to Yuval Harari, adjurations seem to be an essential and decisive part of ancient Jewish magic. ${ }^{3}$ However, these powers are not only evoked by uttering words, but also by writing adjurations, magical names, and signs. Accordingly, writing these magical words, names, or signs induces the intended result-such as, for example, binding demons-in the very moment of the writing act itself.

In addition to the performative speech or writing act, I would like to introduce another concept: the performative haptic act. The broader background of this performance is the assumed efficacy of touching someone, for instance, with the hands, as can be seen in different performative haptic acts such as blessing, ordaining, protecting, healing, or cursing. In most cases, the performative haptic act is combined with a performative speech or writing act. For instance, a priest blesses someone by touching her head with his hands and simultaneously saying, "I bless you." Accordingly, in specific cases, the efficacy of ritual and magical power also demands performative haptic acts. By touching a person or an object, the magical practitioner intends to make something happen, such as, for example, healing or harm. In the insider's view, the physical contact enables the flow of supernatural power from one entity to the other. In the very moment in which someone touches someone or something in a ritual act, an essential change is believed to be taking place.

In this regard, James G. Frazer's concept of contagious magic as published in his famous book The Golden Bough can still help us to understand what is happening here. ${ }^{4}$ According to Frazer, two main principles of magic can be distinguished: the Law of Similarity and the Law of Contagion. The main idea behind the Law of Similarity is "that like produces like, or that an effect resembles its cause." In contrast, the Law of Contagion follows the idea "that things which have once been in contact with each other continue to act on each other at a distance after the physical contact has been severed." ${ }^{\prime 6}$ However, both principles can be subordinated under the Law of Sympathy, because they presuppose "that things act on each other at a distance through a secret sympathy." The deeper meaning of the concept of contagious magic is the idea that touching or other forms of direct contact enables the transfer of effective agencies including healing or aggressive powers between the toucher and the touched. Thus, touching with the hands, lips, or other body parts is one specific

3 See Yuval Harari, "What Is a Magical Text? Methodological Reflections Aimed at Redefining Early Jewish Magic," in Officina Magica: Essays on the Practice of Magic in Antiquity, ed. Shaul Shaked (Leiden and Boston: Brill, 2005), 91-124.

4 See James George Frazer, The Golden Bough: A Study in Magic and Religion. A New Abridgement from the Second and Third Editions, ed. Robert Fraser (Oxford: Oxford University Press, 1998), 3745. On Frazer's definition of magic, see, e.g., Bernd-Christian Otto, Magie: Rezeptions- und diskursgeschichtliche Analysen von der Antike bis zur Neuzeit (Berlin: De Gruyter, 2011), 45-60.

5 Frazer, The Golden Bough, 11.

6 Frazer, ibidem.

7 Frazer, 12. 
possibility for establishing this kind of contact. Other forms of direct contact with supernatural powers might include other senses as well, such as sight, hearing, taste, and smell.

On the other hand, the prohibition or caveat concerning touching can define the boundary between different religious, cultic, or even ontological spheres. Thus, one of the usual preconditions for the performance of magical or ritual acts is the prohibition of sexual intercourse; that is, being forbidden to touch another body. Additional preparatory instructions concern dietetic limitations; that is, being forbidden to touch specific food or alcohol. Concepts of purity regarding the regulation of touch are obviously intertwined in religion, ritual, and magic. ${ }^{8}$

In order for magical acts to be effective, a practitioner of magic must not question or deviate from the given instructions. Of course, the same general precondition for a ritual is also true for performative haptic acts. Yet in instances when magic does not work-that is, when the intended purpose is not achieved-it is only natural for the practitioner or the client to begin to doubt the efficacy of the act. Another result would be that failure produces doubts concerning whether the magical act has been properly performed or whether the practitioner is capable of performing it. A typical explanation for failure from inside the system of magical concepts would be that there was something wrong with the preparation and/or performance of the magical act and thus it has to be repeated in the correct way. ${ }^{9}$ The pragmatic response to those challenges would be to reattempt the performative act until it achieves the desired result. So, repetition is one strategy for overcoming failure and doubt. Another pragmatic approach would be to try an alternative set of instructions or recipe promising the same effect. What has to be touched and what must not be touched can be crucial in this respect. In some cases, touching can be interpreted as another attempt to ensure that the transfer of magical power between one thing or person and the other does indeed take place. Thus, touching could be another strategy for overcoming doubts concerning the efficacy of a magical act.

Throughout the Jewish tradition, there is ample evidence of magic. ${ }^{10}$ Unlike anthropologists of contemporary cultures, the scholar of ancient Jewish magic is usually not in the comfortable situation of being able to do fieldwork; that is, to study the performance of magical acts in real time and place. ${ }^{11}$ Most of the material to

8 See Rebecca Macy Lesses, Ritual Practices to Gain Power: Angels, Incantations, and Revelation in Early Jewish Mysticism (Harrisburg: Trinity Press International, 1998), 117-60.

9 See the numerous examples collected in Ute Hüsken, ed., When Rituals Go Wrong: Mistakes, Failure, and the Dynamics of Ritual (Leiden: Brill, 2007).

10 See the surveys in Gideon Bohak, Ancient Jewish Magic: A History (Cambridge: Cambridge University Press, 2008); Yuval Harari, Jewish Magic before the Rise of Kabbalah, trans. Batya Stein (Detroit: Wayne State University Press, 2017); Joshua Trachtenberg, Jewish Magic and Superstition: A Study in Folk Religion (New York: Atheneum, 1970).

11 On pragmatic interpretations of magical texts, see Bill Rebiger, "Unterweisung, Überlieferung und Aktualisierung von magischem Wissen im Judentum: Ansätze zu einer Textpragmatik,” Frankfurter Judaistische Beiträge 36 (2010): 31-55. 
be studied in Jewish magic is only textual. ${ }^{12}$ However, one of the greatest peculiarities of Jewish magic is this textual character and its references to other works such as biblical and liturgical texts. Quotations, adaptations, and allusions are common methods in the use of these canonical texts. ${ }^{13}$ Another essential characteristic of Jewish magic is the obsession with divine, angelic, demonic, or other magical names and signs and the supposed efficacy of their use in magical acts. ${ }^{14}$

Besides the textual character of Jewish magic, I also want to emphasise another aspect of it, which is the material and haptic character of its magical objects and acts. Therefore, it is useful to distinguish between two categories: 1) finished products or applied texts and 2) instructions or recipes. ${ }^{15}$ Finished products or applied texts include, for example, amulets, magic bowls, rings, gems, seals, and even skulls. ${ }^{16}$ One essential feature of finished products defining their haptic dimension is that

12 See Gershom Scholem, "Havdala De-Rabbi 'Aqiva: A Source for the Tradition of Jewish Magic during the Geonic Period" [Hebrew], Tarbiz 50 (1980/81): 243-81 (reprinted in Gershom Scholem, Devils, Demons and Souls: Essays on Demonology, ed. Esther Liebes [Jerusalem: Ben-Zvi Institute for the Study of Jewish Communities in the East, 2004], 145-82); Joseph Naveh and Shaul Shaked, Amulets and Magic Bowls: Aramaic Incantations of Late Antiquity (Jerusalem: Magnes, 1985); Joseph Naveh and Shaul Shaked, Magic Spells and Formulae: Aramaic Incantations of Late Antiquity (Jerusalem: Magnes, 1993); Lawrence H. Schiffman and Michael D. Swartz, Hebrew and Aramaic Incantation Texts from the Cairo Geniza: Selected Texts from Taylor-Schechter Box K1 (Sheffield: JSOT Press, 1992); Peter Schäfer and Shaul Shaked, Magische Texte aus der Kairoer Geniza, 3 vols. (Tübingen: Mohr Siebeck, 1994-99); Yuval Harari, Harba de-Moshe: New Edition and Study [Hebrew] (Jerusalem: Academon Press, 1997); Judah B. Segal, Catalogue of the Aramaic and Mandaic Incantation Bowls in the British Museum (London: British Museum, 2000); Dan Levene, A Corpus of Magic Bowls: Incantation Texts in Jewish Aramaic from Late Antiquity (London: Kegan Paul, 2003); Irina Wandrey, "Das Buch des Gewandes” und “Das Buch des Aufrechten”: Dokumente eines magischen spätantiken Rituals (Tübingen: Mohr Siebeck, 2004); Christa Müller-Kessler, Die Zauberschalentexte in der HilprechtSammlung, Jena, und weitere Nippur-Texte anderer Sammlungen (Wiesbaden: Harrassowitz, 2005); Bill Rebiger and Peter Schäfer, Sefer ha-Razim I und II: Das Buch der Geheimnisse I und II, 2 vols. (Tübingen: Mohr Siebeck, 2009); Bill Rebiger, Sefer Shimmush Tehillim: Buch vom magischen Gebrauch der Psalmen (Tübingen: Mohr Siebeck, 2010); Shaul Shaked, James Nathan Ford, and Siam Bhayro, Aramaic Bowl Spells: Jewish Babylonian Aramaic Bowls, Volume One (Leiden: Brill, 2013); Dan Levene, Jewish Aramaic Curse Texts from Late-Antique Mesopotamia: May These Curses Go Out and Flee (Leiden: Brill, 2013); Gideon Bohak, ed., A Fifteenth-Century Manuscript of Jewish Magic: MS New York Public Library, Heb. 190 (Formerly Sassoon 56). Introduction, Annotated Edition and Facsimile [Hebrew], 2 vols. (Los Angeles: Cherub Press, 2014); Emma Abate, Sigillare il mondo. Amuleti e ricette dalla Genizah: Manoscritti magici ebraici della biblioteca della Alliance Israelite Universelle di Parigi (Palermo: Officina di Studi Medievali, 2015); Oded Porat, ed., Sefer Brit ha-Menuhah: Book of Covenant of Serenity [Hebrew] (Jerusalem: Magnes, 2016).

13 See Dorothea Salzer, Die Magie der Anspielung: Form und Funktion der biblischen Anspielungen in den magischen Texten der Kairoer Geniza (Tübingen: Mohr Siebeck, 2010).

14 See Trachtenberg, Jewish Magic and Superstition, 78-103; Bohak, Ancient Jewish Magic, 305-7. 15 See Bohak, Ancient Jewish Magic, 144-48.

16 On the use of writing materials in Jewish magic, see Bill Rebiger, "Write on Three Ribs of a Sheep': Writing Materials in Ancient and Mediaeval Jewish Magic," in Jewish Manuscript Cultures: New Perspectives, ed. Irina Wandrey (Berlin: De Gruyter, 2017), 339-59. 
they can be grasped, worn, or touched. On the other hand, instructions or recipes describing the production of finished products and/or the performance of a magical act or ritual are usually found in manuscripts such as the fragments from the Cairo Genizah (see below) or printed manuals. The goals of these instructions are familiar ones, such as, for instance, healing, protection, love charms, dream questions, "opening the heart" (i.e., improving learning and memory), and aggressive magic. Concerning this second category of instructional texts, the imperative to touch or to avoid touching defines the haptic character of the magical acts.

In order to understand the haptic dimension of ancient and medieval Jewish magic, it may be useful to present and discuss some sample texts in what follows. It must be emphasised that only a very limited selection of texts can be given here. First, I would like to begin with two significant narratives from the Hebrew Bible and one from the New Testament. In these biblical texts, touching defines the boundary between the sacred and the profane or between charismatic wonderworkers and the common people. Following the biblical examples, I would like to focus on medieval instructional texts of Jewish magic and the meaning of human touching and other forms of direct contact for the performance of magical acts. As we will see, a significant difference concerning human touching can be observed from comparing biblical stories of wonder-workers with texts giving instructions for how to perform magical acts.

\section{Sample Texts}

\section{1) 2 Samuel $6: 2-7$}

The first text is about the lethal boundary between the sacred and the profane realms, or between the initiated people-that is, the priests-on the one side and the laymen on the other. Here, the numinous and frightening character of the incident is telling: not only for the present reader, but also for the people in the story itself. The text deals with a sacred object, the Ark of the Covenant, and the danger of touching it:

2 Then David and all the troops that were with him set out from Baalim of Judah to bring up from there the Ark of God to which the Name was attached, the name LORD of Hosts Enthroned on the Cherubim.

3 They loaded the Ark of God onto a new cart and conveyed it from the house of Abinadab, which was on the hill; and Abinadab's sons, Uzzah and Ahio, guided the new cart.

4 They conveyed it from Abinadab's house on the hill, [Uzzah walking] alongside the Ark of God and Ahio walking in front of the Ark.

5 Meanwhile, David and all the House of Israel danced before the LORD to [the sound of] all kinds of cypress wood [instruments], with lyres, harps, timbrels, sistrums, and cymbals. 
6 But when they came to the threshing floor of Nacon, Uzzah reached out for the Ark of God and grasped it, for the oxen had stumbled.

7 The LORD was incensed at Uzzah. And God struck him down on the spot for his indiscretion, and he died there beside the Ark of God. ${ }^{17}$

The bitter irony of this story is that Uzzah, whose only goal in touching the ark is to prevent it from falling, is fatally punished by God for doing so. ${ }^{18}$ Touching the sacred object is lethal to him simply because he does not belong to the priestly caste, whose members are the only people who are allowed to approach it. Thus, this story, like others in the Hebrew Bible, ${ }^{19}$ emphasises that for anyone who does not belong to the initiated people, there is a caveat and a prohibition against touching sacred objects which are supposed to be charged with supernatural and, more specifically, aggressive power. So, it is no wonder that these allegedly powerful objects were not only venerated, but also used for magical purposes. Throughout the history of Judaism-as in that of other religions as well-we find a great deal of evidence for the magical use of Holy Scriptures ${ }^{20}$ and cultic doorposts or mezuzot ${ }^{21}$ with regard to their materiality. In contrast to the biblical account, touching the objects is one of the commonest and most well-established practices.

\section{2) 2 Kings 4:29-35}

In the Hebrew Bible-as in the Holy Scriptures of other religions-there are many stories of holy or charismatic men performing wondrous deeds and miracles. In general, these miracles bend or abrogate natural laws with the help of divine power. Among the wonder-working men of God mentioned in the Hebrew Bible are the prophet Elijah and his disciple and successor Elisha. ${ }^{22}$ On the simple narrative level, the events are dated to the ninth century BCE, although the literary account was certainly composed much later. The following story of one of the miracles performed by Elisha is

172 Sam 6:2-7 (New JPS Translation).

18 See Bohak, Ancient Jewish Magic, 28.

19 See, e.g., Exod 19:12, where the Israelites are exhorted not to touch Mount Sinai, or Lev 10:1-2, where Aaron's sons die after entering the sanctuary. See also the well-known Latin phrase noli me tangere ("touch me not") translated from the Greek in John 20:17, which Jesus says to Mary Magdalene.

20 See, e.g., Peter Ganz, ed., Das Buch als magisches und als Repräsentationsobjekt (Wiesbaden: Harrassowitz, 1992); Shalom Sabar, "Torah and Magic: The Torah Scroll and Its Accessories in Jewish Culture in Europe and in Muslim Countries” [Hebrew], Pe'amim 85 (2000): 149-79.

21 See Yuval Harari, "Leadership, Authority, and the 'Other' in the Debate over Magic from the Karaites to Maimonides," The Journal for the Study of Sephardic and Mizrahi Jewry 1, no. 2 (2007): 97. 22 On the biblical prophet as a channel for God's power when performing miracles, see Ann Jeffers, Magic and Divination in Ancient Palestine and Syria (Leiden: Brill, 1996), 81-95. On Elijah and Elisha as wonder-workers, see Bohak, Ancient Jewish Magic, 20-27. 
divided into two parts. The first is about the delegation of magical power involving the use of a magic wand and the failure of the magical act. The second, in contrast, describes the success of a different magical act performed by the prophet himself. Prior to this event, Elisha prophesied to a childless woman that she would give birth to a son. However, when the child dies at an early age, Elisha takes action:

29 He [i.e., Elisha] said to [his servant] Gehazi, "Tie up your skirts, take my staff in your hand, and go. If you meet anyone, do not greet him; and if anyone greets you, do not answer him. And place my staff on the face of the boy.” [...]

31 Gehazi had gone on before them and had placed the staff on the boy's face; but there was no sound or response. He turned back to meet him [i.e., Elisha] and told him, "The boy has not awakened."

32 Elisha came into the house, and there was the boy, laid out dead on his couch.

33 He went in, shut the door behind the two of them, and prayed to the LORD.

34 Then he mounted [the bed] and placed himself over the child. He put his mouth on its mouth, his eyes on its eyes, and his hands on its hands, as he bent over it. And the body of the child became warm.

35 He stepped down, walked once up and down the room, then mounted and bent over him. Thereupon, the boy sneezed seven times, and the boy opened his eyes. ${ }^{23}$

In the first part of the story quoted above, Elisha's servant Gehazi fails despite having done exactly what his master instructed him to do. As Elisha's servant, he is very close to his master and is thus somewhat elevated. Therefore, he is even allowed to use Elisha's own staff for the performance of the ritual act. However, his attempt to resurrect the dead boy fails. Despite the general idea of an almost mechanical causality in magic, there is in fact no certainty or guarantee of success in the performance of ritual or magical acts. Failure is always possible and each failed attempt evokes further doubts concerning the correctness of the instructions and their execution. In this story, two ways of overcoming this scepticism are presented. First, only the prophet Elisha himself, who has been chosen by God, can succeed in performing miracles. Elisha's prayer does not merely emphasise this close relationship between God and his prophet; rather, it is already part of the ritual performance. Second, it is only Elisha's double execution of the performative haptic act of bodily touching that enables his magical power to flow directly into the boy's body. ${ }^{24}$ In doing so, Elisha

232 Kgs 4:29-35 (New JPS Translation). For a discussion of this passage, see, e. g., Rüdiger Schmitt, Magie im Alten Testament (Münster: Ugarit-Verlag, 2004), 237-50; Michael Pietsch, "Der Prophet als Magier: Magie und Ritual in den Elischaerzählungen," in Zauber und Magie im antiken Palästina und in seiner Umwelt: Kolloquium des Deutschen Vereins zur Erforschung Palästinas vom 14. bis 16. November 2014 in Mainz, ed. Jens Kamlah, Rolf Schäfer, and Markus Witte (Wiesbaden: Harrassowitz, 2017), 359-67. Elisha's action is very similar to that of his master Elijah in 1 Kings 17:19-23.

24 Compare also Naaman's plea to Elisha to heal his leprosy by laying his hands over the afflicted area in 2 Kgs 5:11. 
transgresses the biblical prohibition on touching dead bodies. ${ }^{25}$ Instead, he interconnects those sensory organs or limbs which are immediately indicative of a living being; namely, the boy's mouth, eyes, and hands. The boy's sneezing involves the other two sensory organs; that is, the nose and the ears. The sevenfold occurrence of sneezing is a common motif from magical tales that emphasises the exceptional character of the events. Finally, the opening of the boy's eyes and the increase in his body temperature indicate the success of the resurrection.

Similar to the New Testament story of the Doubting Thomas in John 20:24-29, only a magical touch can dispel scepticism in the end. In other words, the use of a magical technique or item is important, but not sufficient. In line with this, the story of Elisha and Gehazi can be interpreted as a polemic against the layman or non-professional practitioner who believes that it is sufficient to simply execute an instruction in order to achieve a goal. In contrast, only God's holy men are able to perform wonderful deeds with the help of the supernatural power they were given by God.

\section{3) Matthew 8:1-3}

The third example is from the New Testament and presents Jesus as a wonder-working man of God in line, at least to a certain degree, with Elijah and Elisha. This is not the right place to discuss the interpretation that Jesus was merely a magician like many others of his time found in late antique anti-Christian polemics ${ }^{26}$ as well as in modern scholarship. ${ }^{27}$ Matthew 8:1-3 tells the story of Jesus cleansing a leper:

1 When he [i.e., Jesus] came down from the mountain, great crowds followed him.

2 And behold, a leper came to him and knelt before him, saying, "Lord, if you will, you can make me clean."

25 See Num 19:10-22 and, concerning priests, Lev 21:1-3.

26 See Peter Schäfer, Jesus in the Talmud (Princeton: Princeton University Press, 2007), 52-62.

27 See Morton Smith, Jesus the Magician (San Francisco: Harper \& Row, 1978). For criticism of Smith, see, e. g., Jan A. Bühner, "Jesus und die antike Magie: Bemerkungen zu M. Smith, Jesus der Magier," Evangelische Theologie 43 (1983): 156-75; Graham H. Twelftree, Jesus the Exorcist: A Contribution to the Study of the Historical Jesus (Tübingen: Mohr Siebeck, 1993), 190-207; Bernd Kollmann, Jesus und die Christen als Wundertäter: Studien zu Magie, Medizin und Schamanismus in Antike und Christentum (Göttingen: Vandenhoeck \& Ruprecht, 1996), 130-32; Michael Becker, Wunder und Wundertäter im frührabbinischen Judentum: Studien zum Phänomen und seiner Überlieferung im Horizont von Magie und Dämonismus (Tübingen: Mohr Siebeck, 2002), 421-42; Marco Frenschkowski, Mysterien des Urchristentums: Eine kritische Sichtung spekulativer Theorien zum frühen Christentum (Wiesbaden: Marix Verlag, 2007), 211-27. 
3 And Jesus stretched out his hand and touched him, saying, "I will; be clean." And immediately his leprosy was cleansed. ${ }^{28}$

The practice of palm healing is well attested in ancient literature. ${ }^{29}$ The broader background of this practice is the assumed symbolic power of the hand, as can be seen in its different functions such as blessing, ordaining, protecting, healing, or cursing. Similar to the story here, Jesus also heals with the touch of his hand in Mark 5:21$43^{30}$ and Luke 4:40. Until modern times, leprosy was interpreted as a contagious disease that involved cultic impurity and therefore required strict separation between the leper and other people. Touching the leper had to be strictly avoided, and any accidental touch was suspicious. Thus, Jesus touching the sick person with his hand is an abnormal or subversive behaviour with regard to the social and cultic standards of his culture. This kind of inversion is one of the general characteristics of magic. As explicitly mentioned in the story, the healing is dependent on the intention of the healer. The combination of touching and speaking in Jesus's healing of the leper brings the haptic act and the speech act together. The importance of Jesus's miracles for Christianity may have caused a certain aloofness towards the supernatural powers of wonder-workers and the importance of direct bodily contact in medieval Judaism. However, biblical charismatic wonder-workers like Elijah and Elisha eventually became a kind of role model for later magicians, who were called "Master of the Name" or ba'al shem by their followers and admirers in the Jewish tradition. ${ }^{31}$

Besides the stories about of these exceptional men, there is additional evidence of a widespread magical praxis in Judaism which can be found in thousands of instructional texts in manuscripts and printed editions from the Middle Ages onwards. In these texts, the personality of the practitioner is much less important than the correct performance of a magical act. Here, it is more important to follow the instructions for a magical ritual or the recipe for the preparation of a magical ingredient. The rituals involved in descriptions of (biblical) miracles and in medieval magical instructions are indeed very similar in many cases. Nevertheless, one difference is that the medieval Jewish practitioners addressed by these instructions usually do not claim that they are on a mission from God. Another difference is that in contrast to many medieval instructions, the holy men of the Bible do not perform erotic charms. In general, unlike the biblical wonder-workers, the medieval instructions are not concerned with the resuscitation of the dead or rain-making. However, the most important difference is that the medieval Jewish practitioners rely on an ac-

28 Matt 8:1-3 (English Standard Version); compare the synoptic parallels in Mark 1:40-44 and Luke 5:12-14.

29 See, e.g., the Genesis Apocryphon from Qumran, 1QapGen 20:28-29, where Abraham heals the Pharaoh by laying his hands on his head.

30 Compare the synoptic parallels in Matt 9:18-26 and Luke 8:40-56.

31 See Karl E. Grözinger, Tausend Jahre Ba'ale Schem. Jüdische Heiler, Helfer, Magier: Ein Spiegel europäischer Geistesgeschichte (Wiesbaden: Harrassowitz, 2017). 
quired body of technical knowledge and the use of magical material objects and spoken or written words. Therefore, knowledge of the techniques and practices is more important than simply belonging to an elite of God's chosen men. Holy men are defined by election or vocation. In contrast, practitioners of magic attempt to follow instructions. At the same time, magic becomes a knowledge, skill, or technique rather than a gift elevating charismatic individuals.

\section{4) Sefer Shimmush Tehillim ("Book of the Magical Use of Psalms")}

The Sefer Shimmush Tehillim or "Book of the Magical Use of Psalms" is the most popular manual of Jewish magic. ${ }^{32}$ In this book, each biblical psalm is combined with instructions for a magical act intended for a specific purpose. The origins of this book can be dated back to the ninth or tenth century CE. The earliest manuscript evidence can be found in medieval fragments from the Cairo Genizah (see below). After a long and complicated history of compilation and redactions, the first printed edition was published in the small town of Sabbioneta in Northern Italy in $1551 .{ }^{33}$ Since then and to this day, it has been reprinted many times. One very typical instruction in this manual is designed to heal an unhealthy spleen:

Write [the verses of Psalm 119:49-56] on the side of the spleen. ${ }^{34}$

In fact, writing the relevant text of the eight verses from Psalm 119 on the unhealthy person's body is a kind of magical tattooing. ${ }^{35}$ In analogy to the alleged divine origin of the Torah, the five books of Moses, the supposed Davidic authorship of the psalms guarantees their magical power. The direct contact between the magical writing and the bodily location of the disease is a wonderful example of Frazer's concept of contagious magic. This contact enables the transmission of the magical power and thus replaces the magical touch of a charismatic healer or wonder-worker. The haptic act of human touching is mediated by another haptic act: the physical contact between the effective Bible verses and the specific part of the body. Here, the combination of a performative writing act and a haptic act guarantees the efficacy of the healing spell. The key element is the idea that the spleen will inevitably be affected by the magical writing. Other very common techniques for establishing direct contact between mag-

32 See Rebiger, Sefer Shimmush Tehillim; Rebiger, "Die magische Verwendung von Psalmen im Judentum," in Ritual und Poesie: Formen und Orte religiöser Dichtung im Alten Orient, im Judentum und im Christentum, ed. Erich Zenger (Freiburg im Breisgau: Herder, 2003), 265-81.

33 See Bill Rebiger, “The editio princeps of Sefer Šimmuš Tehillim, Sabbioneta 1551,” in L'Eredità di Salomone. La magia ebraica in Italia e nel Mediterraneo, ed. Emma Abate (Florence: Giuntina, 2019), 169-84.

34 Rebiger, Sefer Shimmush Tehillim, 88*-89*: section 135.

35 See Bohak, Ancient Jewish Magic, 118-19. 
ical writing and the transmission of magical agency include eating inscribed food such as cakes or eggs or dissolving the writing in a liquid and drinking it. ${ }^{36}$

\section{5) A Genizah fragment}

The fragments from the so-called Cairo Genizah have provided the scholarly world with a huge amount of material. A Genizah is a kind of synagogue storehouse in which unused manuscripts containing the name of God are collected. The most famous of these is the Cairo Genizah, which was discovered in the late nineteenth century by the Cambridge scholar Solomon Schechter and which contained more than 400,000 fragments spanning from the ninth to the nineteenth century, most of which are medieval. These fragments are now held in collections in Cambridge, Oxford, New York, and elsewhere. ${ }^{37}$ The following Genizah fragment contains, among many others, a very typical set of instructions for healing magic:

For the sting of a scorpion, write [the following magical names] over the pain[ful spot]:

'qrws

Qrws

Rws

Ws

s. $^{38}$

Here again, as in the sample text from the Sefer Shimmush Tehillim quoted above, the ideas of magical tattooing and of direct contact between the effective writing and the location of the pain are essential for understanding the magical act. However, one difference between these two examples is that in the second case, the problem has a cause that is external to the body. In both cases, it is not the touch of a wonder-worker that guarantees the healing, but rather a magical act that can be performed by anyone. Or, in other words: it is not the charisma of an elite man chosen by God that provides the magical agency, but rather magical names. In addition, the magical name used does not originate in the Bible, but belongs to a separate and genuine magical tradition. This name, consisting of the five Hebrew letters 'qrws (אקרוס) and probably of Greek origin (äkpos), ${ }^{39}$ has no semantic meaning in the He-

36 See Bill Rebiger, "Wein in der jüdischen Magie des Mittelalters," in Wein und Judentum, ed. Andreas Lehnardt (Berlin: Neofelis Verlag, 2014), 103-7.

37 See Stefan C. Reif, A Jewish Archive from Old Cairo: The History of Cambridge University's Genizah Collection (Richmond: Curzon Press, 2000); Adina Hoffman and Peter Cole, Sacred Trash: The Lost and Found World of the Cairo Geniza (New York: Schocken, 2011).

38 CUL T.-S. K 1.117, page 5, lines 12-17, edited in Naveh and Shaked, Magic Spells and Formulae, 17879 (Geniza 16).

39 The Greek word ökpoৎ (akros) means “outermost" or "extreme," which is somewhat fitting given the sting of the scorpion. 
brew language, but becomes a powerful name in these magical instructions. The graphic vanishing of the magical name, made up of five letters which disappear one by one in each successive line, symbolises the vanishing of the pain.

\section{6) Another Genizah fragment}

In another Genizah fragment, we find instructions for a treasure hunt:

To make a candle in order to look for treasure with it, take new wax, a new vessel, sulphur, and the fingerbones of a corpse. Pound it well and mix all together. Take a hanged man's rope and make a wick [for the candle] with it. [...] When you reach the place where you should dig, the candle will extinguish. ${ }^{40}$

In the context of the instructions, the corpse's index finger is an indication that "points" the treasure seeker in the right direction. Both the corpse and the hanged man symbolise the underworld, which is also the location of the presumed treasure. Here, a finger symbolically touches the correct place. This magical act promises that a treasure will be found despite the practitioner having no prior knowledge of its location.

In the rabbinical magico-medical manual imbedded in the Babylonian Talmud, Tractate Gittin (bGit 68b-70b), we find a recipe for healing the spleen in which the hand of a corpse is used. This recipe explicitly mentions the sympathetic concept behind the practice: just as the corpse's hand is dry, so the spleen will also dry out. ${ }^{41}$

\section{7) Ḥarba de-Moshe ("Sword of Moses")}

A last sample text can be found in Harba de-Moshe or "Sword of Moses." This magical text was written in Hebrew in the second half of the first millennium CE. In the main part of this book, numerous instructions using the so-called sword are compiled. The "Sword" contains long series of magical names, most of which are ineffable, and instructions involving these names. Many nomina barbara-that is, strange names-and technical terms found in this book appear to have a Greek origin. One of the instructions deals with catching thieves:

For [catching] thieves, say: May thieves and robbers be bound and surrender in the name of MRGWHMHW'L until 'TTTHSHW'L, and while reciting [it] put your little finger in your ear

40 CUL T.-S. K 1.3, fol. 2b/15-3a/4, edited in Schäfer and Shaked, Magische Texte aus der Kairoer Geniza, vol. 3, 93: no. 62 (my translation).

41 See Giuseppe Veltri, Magie und Halakha: Ansätze zu einem empirischen Wissenschaftsbegriff im spätantiken und frühmittelalterlichen Judentum (Tübingen: Mohr Siebeck, 1997), 247. 
[while reciting it]. And when you wish to release them, say from Y’WYHW and remove your hand from your ear. ${ }^{42}$

In these instructions for a performative speech act, there is an impressive demonstration of the efficacy of the magical spell. In order to be protected from the magical power, one has to avoid hearing the spell during the performance. Here, the touching of the ears serves as a prevention of sense perception; that is, the sense of hearing. Thus, in this case, touching interrupts the transmission of magical agency, which is completely different to the above-mentioned sample texts. The simultaneous performance of the haptic act of touching and the speech act of the adjuration channels the magical agency to the right addressees; that is, the thieves.

\section{Conclusion}

The knowledge of the meaning of touching and the acceptance of related instructions is in many cases vital for the performance of magical acts. The introduction of the concept of performative haptic acts emphasises the function of touching in these acts. The first sample text, the story of Uzzah in 2 Samuel 6:2-7 presents the lethal consequences for unauthorised persons when they transgress the prohibitions on touching sacred objects. Here, touching defines the border between sanctity/profanity and purity/impurity.

In cases where the intended purpose of a magical act did not appear to have been achieved, there was doubt as to whether the person who had performed it had done so correctly. In the story of Elisha's resurrection of the dead child in 2 Kings 4:29-35, the failure of the magical act performed by the servant Gehazi is repaired: firstly by the healing act being performed by the wonder-worker himself and secondly by introducing a performative haptic act in order to ensure the transmission of the effective power between the holy man of God and the dead person.

Similar to Elisha's account, the third sample text from the New Testament in which Jesus heals the leper again emphasises the function of the performative haptic act of bodily touching. Both Elisha and Jesus transgress the biblical prohibition by touching either a dead body or a leper.

A closer look at the biblical texts presented above raises the question of the subject of a magical act, or, to focus more on our topic, whether it is who is doing the touching that is important. The wonder-worker is interpreted as a kind of vessel for the supernatural power which comes from God. Thus, the flow of this power from God to the client or object can be guaranteed by touching during a performative haptic act.

42 See Yuval Harari, “The Sword of Moses (Harba de-Moshe): A New Translation and Introduction,” Magic, Ritual, and Witchcraft 7 (2012): 96, no. 132-33. 
In contrast, Jewish magical instructions from the Middle Ages and early modern times suggest, at least at first sight, that anyone who knows the appropriate instructions and recipes is able to be effective and successful as long as he or she follows them correctly. Thus, in many cases, the mediated contact between magically effective verses or names and the addressee of the magical ritual replaces a human touch from a charismatic man. In these cases, the efficacy of contagious magic is in fact less dependent on the magical power transmitted by a holy man than on depersonalised forms of contact. Accordingly, in the (medieval) instructional texts intended for any practitioner, the performative haptic act is much less important than it is in the miracles performed by wonder-workers as described in the biblical stories. However, the two phenomena, the magic of the wonder-worker and that of the common practitioner, do not exclude each other. Thus, there were numerous charismatic wonder-workers in Judaism-such as, for example, in Lurianic Kabbalah and Hasidism-who were very familiar with the knowledge of how to perform a magical act as presented in instructional texts. ${ }^{43}$

\section{Bibliography}

Abate, Emma. Sigillare il mondo. Amuleti e ricette dalla Genizah: Manoscritti magici ebraici della biblioteca della Alliance Israelite Universelle di Parigi. Palermo: Officina di Studi Medievali, 2015.

Austin, J.L. How to Do Things with Words: The William James Lectures Delivered at Harvard University in 1955. Edited by J.O. Urmson. Oxford: Clarendon Press, 1962.

Becker, Michael. Wunder und Wundertäter im frührabbinischen Judentum: Studien zum Phänomen und seiner Überlieferung im Horizont von Magie und Dämonismus. Tübingen: Mohr Siebeck, 2002.

Belliger, Andréa, and David J. Krieger, eds. Ritualtheorien: Ein einführendes Handbuch. Opladen: Westdeutscher Verlag, 1998.

Bohak, Gideon. Ancient Jewish Magic: A History. Cambridge: Cambridge University Press, 2008.

Bohak, Gideon, ed. A Fifteenth-Century Manuscript of Jewish Magic: MS New York Public Library, Heb. 190 (Formerly Sassoon 56). Introduction, Annotated Edition and Facsimile [Hebrew]. 2 vols. Los Angeles: Cherub Press. 2014.

Bühner, Jan A. "Jesus und die antike Magie: Bemerkungen zu M. Smith, Jesus der Magier.” Evangelische Theologie 43 (1983): 156-75.

Denny, Frederick Mathewson. "Hands." In Encyclopedia of Religion, Second Edition, edited by Lindsay Jones, 6:3769-71. Detroit: Thomson Gale, 2005.

Fine, Lawrence. Physician of the Soul, Healer of the Cosmos: Isaac Luria and His Kabbalistic Fellowship. Stanford: Stanford University Press, 2003.

Frazer, James George. The Golden Bough: A Study in Magic and Religion. A New Abridgement from the Second and Third Editions. Edited by Robert Fraser. Oxford: Oxford University Press, 1998.

43 See Lawrence Fine, Physician of the Soul, Healer of the Cosmos: Isaac Luria and His Kabbalistic Fellowship (Stanford: Stanford University Press, 2003); Moshe Idel, Hasidism: Between Ecstasy and Magic (Albany, NY: SUNY Press, 1995). 
Frenschkowski, Marco. Mysterien des Urchristentums: Eine kritische Sichtung spekulativer Theorien zum frühen Christentum. Wiesbaden: Marix Verlag, 2007.

Ganz, Peter, ed. Das Buch als magisches und als Repräsentationsobjekt. Wiesbaden: Harrassowitz, 1992.

Grözinger, Karl E. Tausend Jahre Ba'ale Schem. Jüdische Heiler, Helfer, Magier: Ein Spiegel europäischer Geistesgeschichte. Wiesbaden: Harrassowitz, 2017.

Harari, Yuval. Harba de-Moshe: New Edition and Study. [Hebrew.] Jerusalem: Academon Press, 1997.

Harari, Yuval. Jewish Magic before the Rise of Kabbalah. Translated by Batya Stein. Detroit: Wayne State University Press, 2017.

Harari, Yuval. “Leadership, Authority, and the 'Other' in the Debate over Magic from the Karaites to Maimonides." The Journal for the Study of Sephardic and Mizrahi Jewry 1, no. 2 (2007): 79-101.

Harari, Yuval. "The Sword of Moses (Harba de-Moshe): A New Translation and Introduction." Magic, Ritual, and Witchcraft 7 (2012): 58-98.

Harari, Yuval. "What Is a Magical Text? Methodological Reflections Aimed at Redefining Early Jewish Magic." In Officina Magica: Essays on the Practice of Magic in Antiquity, edited by Shaul Shaked, 91-124. Leiden and Boston: Brill, 2005.

Hoffman, Adina, and Peter Cole. Sacred Trash: The Lost and Found World of the Cairo Geniza. New York: Schocken, 2011.

Hüsken, Ute, ed. When Rituals Go Wrong: Mistakes, Failure, and the Dynamics of Ritual. Leiden: Brill, 2007.

Idel, Moshe. Hasidism: Between Ecstasy and Magic. Albany, NY: SUNY Press, 1995.

Jeffers, Ann. Magic and Divination in Ancient Palestine and Syria. Leiden: Brill, 1996.

Kollmann, Bernd. Jesus und die Christen als Wundertäter: Studien zu Magie, Medizin und Schamanismus in Antike und Christentum. Göttingen: Vandenhoeck \& Ruprecht, 1996.

Lesses, Rebecca Macy. Ritual Practices to Gain Power: Angels, Incantations, and Revelation in Early Jewish Mysticism. Harrisburg: Trinity Press International, 1998.

Levene, Dan. A Corpus of Magic Bowls: Incantation Texts in Jewish Aramaic from Late Antiquity. London: Kegan Paul, 2003.

Levene, Dan. Jewish Aramaic Curse Texts from Late-Antique Mesopotamia: May These Curses Go Out and Flee. Leiden: Brill, 2013.

Müller-Kessler, Christa. Die Zauberschalentexte in der Hilprecht-Sammlung, Jena, und weitere Nippur-Texte anderer Sammlungen. Wiesbaden: Harrassowitz, 2005.

Naveh, Joseph, and Shaul Shaked. Amulets and Magic Bowls: Aramaic Incantations of Late Antiquity. Jerusalem: Magnes, 1985.

Naveh, Joseph, and Shaul Shaked. Magic Spells and Formulae: Aramaic Incantations of Late Antiquity. Jerusalem: Magnes, 1993.

Otto, Bernd-Christian. Magie: Rezeptions- und diskursgeschichtliche Analysen von der Antike bis zur Neuzeit. Berlin: De Gruyter, 2011.

Parrinder, Geoffrey. "Touching." In Encyclopedia of Religion, Second Edition, edited by Lindsay Jones, 13:9255-60. Detroit: Thomson Gale, 2005.

Pietsch, Michael. “Der Prophet als Magier: Magie und Ritual in den Elischaerzählungen.” In Zauber und Magie im antiken Palästina und in seiner Umwelt: Kolloquium des Deutschen Vereins zur Erforschung Palästinas vom 14. bis 16. November 2014 in Mainz, edited by Jens Kamlah, Rolf Schäfer, and Markus Witte, 343-80. Wiesbaden: Harrassowitz, 2017.

Porat, Oded, ed. Sefer Brit ha-Menuhah: Book of Covenant of Serenity [Hebrew]. Jerusalem: Magnes, 2016. 
Rebiger, Bill. "Die magische Verwendung von Psalmen im Judentum." In Ritual und Poesie: Formen und Orte religiöser Dichtung im Alten Orient, im Judentum und im Christentum, edited by Erich Zenger, 265-81. Freiburg im Breisgau: Herder, 2003.

Rebiger, Bill, ed. Sefer Shimmush Tehillim: Buch vom magischen Gebrauch der Psalmen. Tübingen: Mohr Siebeck, 2010.

Rebiger, Bill. "Unterweisung, Überlieferung und Aktualisierung von magischem Wissen im Judentum: Ansätze zu einer Textpragmatik.” Frankfurter Judaistische Beiträge 36 (2010): 3155.

Rebiger, Bill. "Wein in der jüdischen Magie des Mittelalters." In Wein und Judentum, edited by Andreas Lehnardt, 97-120. Berlin: Neofelis Verlag, 2014.

Rebiger, Bill. "'Write on Three Ribs of a Sheep': Writing Materials in Ancient and Mediaeval Jewish Magic." In Jewish Manuscript Cultures: New Perspectives, edited by Irina Wandrey, 339-59. Berlin: De Gruyter, 2017.

Rebiger, Bill. "The editio princeps of Sefer Šimmuš Tehillim, Sabbioneta 1551." In L'Eredità di Salomone: La magia ebraica in Italia e nel Mediterraneo, edited by Emma Abate, 169-84. Florence: Giuntina, 2019.

Rebiger, Bill, and Peter Schäfer, eds. Sefer ha-Razim I und II: Das Buch der Geheimnisse I und II. 2 vols. Tübingen: Mohr Siebeck, 2009.

Reif, Stefan C. A Jewish Archive from Old Cairo: The History of Cambridge University's Genizah Collection. Richmond: Curzon Press, 2000.

Sabar, Shalom. "Torah and Magic: The Torah Scroll and Its Accessories in Jewish Culture in Europe and in Muslim Countries" [Hebrew]. Pe'amim 85 (2000): 149-79.

Salzer, Dorothea. Die Magie der Anspielung: Form und Funktion der biblischen Anspielungen in den magischen Texten der Kairoer Geniza. Tübingen: Mohr Siebeck, 2010.

Schäfer, Peter. Jesus in the Talmud. Princeton: Princeton University Press, 2007.

Schäfer, Peter, and Shaul Shaked. Magische Texte aus der Kairoer Geniza. 3 vols. Tübingen: Mohr Siebeck, 1994-99.

Schiffman, Lawrence H., and Michael D. Swartz. Hebrew and Aramaic Incantation Texts from the Cairo Geniza: Selected Texts from Taylor-Schechter Box K1. Sheffield: JSOT Press, 1992.

Schmitt, Rüdiger. Magie im Alten Testament. Münster: Ugarit-Verlag, 2004.

Scholem, Gershom. "Havdala De-Rabbi 'Aqiva: A Source for the Tradition of Jewish Magic during the Geonic Period" [Hebrew]. Tarbiz 50 (1980/81): 243-81. Reprinted in Gershom Scholem, Devils, Demons and Souls: Essays on Demonology, edited by Esther Liebes, 145-82. Jerusalem: Ben-Zvi Institute for the Study of Jewish Communities in the East, 2004.

Searle, John R. Speech Acts: An Essay in the Philosophy of Language. Cambridge: Cambridge University Press, 1969.

Segal, Judah B. Catalogue of the Aramaic and Mandaic Incantation Bowls in the British Museum. London: British Museum, 2000.

Shaked, Shaul, James Nathan Ford, and Siam Bhayro. Aramaic Bowl Spells: Jewish Babylonian Aramaic Bowls, Volume One. Leiden: Brill, 2013.

Smith, Morton. Jesus the Magician. San Francisco: Harper \& Row, 1978.

Trachtenberg, Joshua. Jewish Magic and Superstition: A Study in Folk Religion. New York: Atheneum, 1970.

Twelftree, Graham H. Jesus the Exorcist: A Contribution to the Study of the Historical Jesus. Tübingen: Mohr Siebeck, 1993.

Veltri, Giuseppe. Magie und Halakha: Ansätze zu einem empirischen Wissenschaftsbegriff im spätantiken und frühmittelalterlichen Judentum. Tübingen: Mohr Siebeck, 1997.

Wandrey, Irina. "Das Buch des Gewandes" und "Das Buch des Aufrechten": Dokumente eines magischen spätantiken Rituals. Tübingen: Mohr Siebeck, 2004. 
Wirth, Uwe, ed. Performanz: Zwischen Sprachphilosophie und Kulturwissenschaften. Frankfurt am Main: Suhrkamp, 2002. 